\title{
Quaternary active tectonic structures in the offshore Bajo Segura basin (SE Iberian Peninsula - Mediterranean Sea)
}

\author{
H. Perea ${ }^{1,2}$, E. Gràcia ${ }^{2}$, P. Alfaro ${ }^{3}$, R. Bartolomé ${ }^{2}$, C. Lo Iacono ${ }^{2}$, X. Moreno ${ }^{2}$, E. Masana ${ }^{4}$, and \\ EVENT-SHELF Team* \\ ${ }^{1}$ LATTEX - IDL, GeoFCUL, Universidade de Lisboa, Ed.C6, Campo Grande 1749-016 Lisbon, Portugal \\ ${ }^{2}$ Unitat de Tecnologia Marina - CSIC, Centre Mediterrani d'Investigacions Marines i Ambientals, Psg. Marítim de la \\ Barceloneta, 37-49, 08003, Barcelona, Spain \\ ${ }^{3}$ Dept. de Ciencias de la Tierra y del Medio Ambiente, Universidad de Alicante, Apdo. 99, 03080 Alicante, Spain \\ ${ }^{4}$ RISKNAT, Dept. Geodinàmica i Geofísica, Universitat de Barcelona, Martí Franqués, s/n, 08028 Barcelona, Spain \\ *M. Farran (ICM-CSIC), E. Andara (IGME), S. Pérez and M. Román Alpiste (UG)
}

Correspondence to: H. Perea (hperea@cmima.csic.es)

Received: 23 March 2012 - Revised: 19 July 2012 - Accepted: 6 August 2012 - Published: 23 October 2012

\begin{abstract}
The Bajo Segura fault zone (BSFZ) is the northern terminal splay of the Eastern Betic shear zone (EBSZ), a large left-lateral strike-slip fault system of sigmoid geometry stretching more than $450 \mathrm{~km}$ from Alicante to Almería. The BSFZ extends from the onshore Bajo Segura basin further into the Mediterranean Sea and shows a moderate instrumental seismic activity characterized by small earthquakes. Nevertheless, the zone was affected by large historical earthquakes of which the largest was the 1829 Torrevieja earthquake ( $I_{\text {EMS98 }} \mathrm{X}$ ). The onshore area of the BSFZ is marked by active transpressive structures (faults and folds), whereas the offshore area has been scarcely explored from the tectonic point of view. During the EVENT-SHELF cruise, a total of 10 high-resolution single-channel seismic sparker profiles were obtained along and across the offshore Bajo Segura basin. Analysis of these profiles resulted in (a) the identification of 6 Quaternary seismo-stratigraphic units bounded by five horizons corresponding to regional erosional surfaces related to global sea level lowstands; and (b) the mapping of the active sub-seafloor structures and their correlation with those described onshore. Moreover, the results suggest that the Bajo Segura blind thrust fault or the Torrevieja left-lateral strike-slip fault, with prolongation offshore, could be considered as the source of the 1829 Torrevieja earthquake. These data improve our understanding of present deformation along the BSFZ and provide new insights into the seismic hazard in the area.
\end{abstract}

\section{Introduction}

The present-day crustal deformation of the southeastern Iberian margin is driven mainly by the NW-SE convergence (4-5 $\mathrm{mm} \mathrm{yr}^{-1}$ ) between the African and Eurasian plates (Argus et al., 1989; DeMets et al., 1990; Serpelloni et al., 2007; Vernant et al., 2010; Koulali et al., 2011). This convergence is accommodated over a wide deformation zone with significant seismic activity south of the Iberian Peninsula (Buforn et al., 1995; Grimison and Cheng, 1986; Morel and Meghraoui, 1996). In the southeastern Iberian margin (Fig. 1), the Neogene and Quaternary faulting activity is dominated by a large left-lateral strike-slip fault system of sigmoid geometry known as the Eastern Betic Shear Zone (EBSZ) (De Larouzière et al., 1988; Silva et al., 1993). The EBSZ stretches more than $450 \mathrm{~km}$ from Alicante to Almería, and includes, from north to south, the Bajo Segura, Carrascoy, Alhama de Murcia, Palomares and Carboneras faults (e.g. Bousquet, 1979; Silva et al., 1993). Instrumental seismicity is mainly characterized by low to moderate magnitude events. Nevertheless, historically, major destructive events such as the 1522 Almería ( $I_{\text {EMS98 }}$ IX), the 1829 Torrevieja

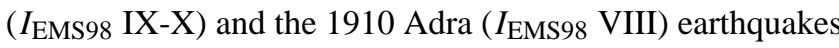
occurred in the area (IGN, 2011).

In this paper, we focus on the northern termination of the EBSZ, the Bajo Segura fault zone (BSFZ). This area is marked by moderate instrumental seismic activity and low magnitude earthquakes (Figs. 1 and 2). Nevertheless, this 


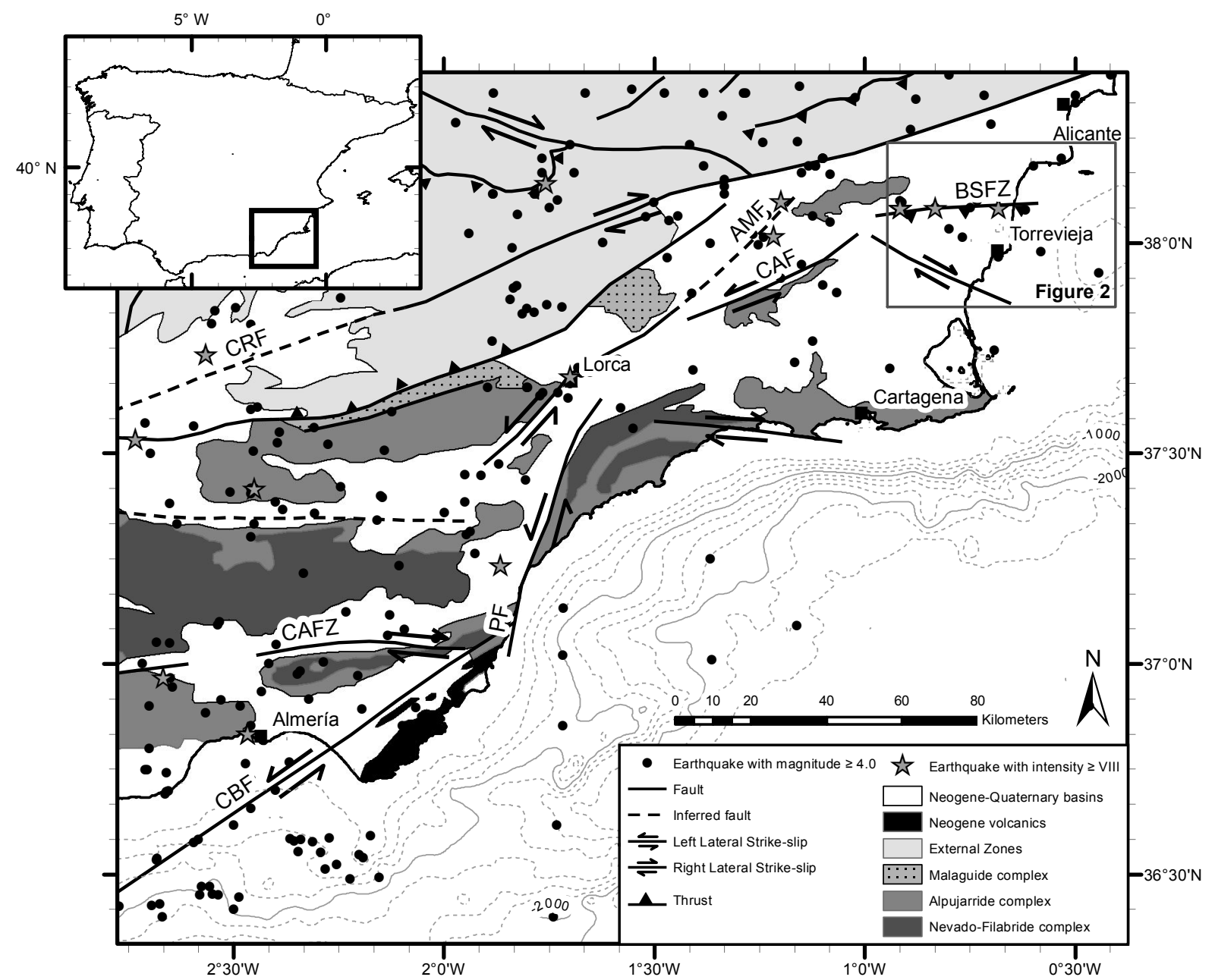

Fig. 1. Regional bathymetric (contour interval $250 \mathrm{~m}$ ) and simplified geological map (Sanz de Galdeano et al., 1995) of the southeastern Iberian margin with historical (gray stars) and instrumental (black dots) seismicity (IGN, 2011). Fault kinematics refers to Upper Neogene. BSFZ: Bajo Segura fault zone; CRF: Crevillente fault; AMF: Alhama de Murcia fault; PF: Palomares fault; CAFZ: Corredor de las Alpujarras fault zone; CBF: Carboneras fault; CAF: Carrascoy fault. The black outlined rectangle shows the study area corresponding to Fig. 2. Inset: Iberian Peninsula map, where the black outlined rectangle corresponds to the area depicted in this figure.

zone has been affected by moderate to large historical earthquakes of which the largest is the 1829 Torrevieja earthquake (IEMS98 IX-X) (López Marinas, 1976; Mezcua, 1982; Rodríguez de la Torre, 1984; Muñoz et al., 1984; Albini and Rodríguez de la Torre, 2001; Martínez Solares and Mezcua, 2002). The onshore portion of the BSFZ comprises active faults and folds resulting from the transpressive setting established in the Plio-Pleistocene (Montenat, 1977; Taboada et al., 1993; Silva et al., 1993; Alfaro et al., 2002a, b, 2012). By contrast, the offshore area is almost devoid of tectonic data (Alfaro et al., 2002b).

In September 2008, using high-resolution single channel seismic (SCS) sparker system, the marine geophysical EVENT-SHELF cruise sought to obtain images of the subseafloor structures in the offshore area of the EBSZ to be integrated with the onshore data to better understand the re- cent faulting history of the SE Iberian margin and characterize its seismic potential. The specific objectives in the BSFZ were (a) to identify the main seismo-stratigraphic units of the area and localize the main tectonic structures in the offshore basin; (b) to correlate the offshore structures with the well-known onshore structures; (c) to determine which structures have been active during the Quaternary and are potential sources of future earthquakes; and (d) to consider the possibility that an offshore structure could be the source that produced the 1829 Torrevieja earthquake. The lack of offshore data is a common problem in coastal areas and particularly in the Mediterranean. This work shows how critical the integration of onshore and offshore data is to a better understanding and characterization of the seismic potential of the active faults located in these areas. 


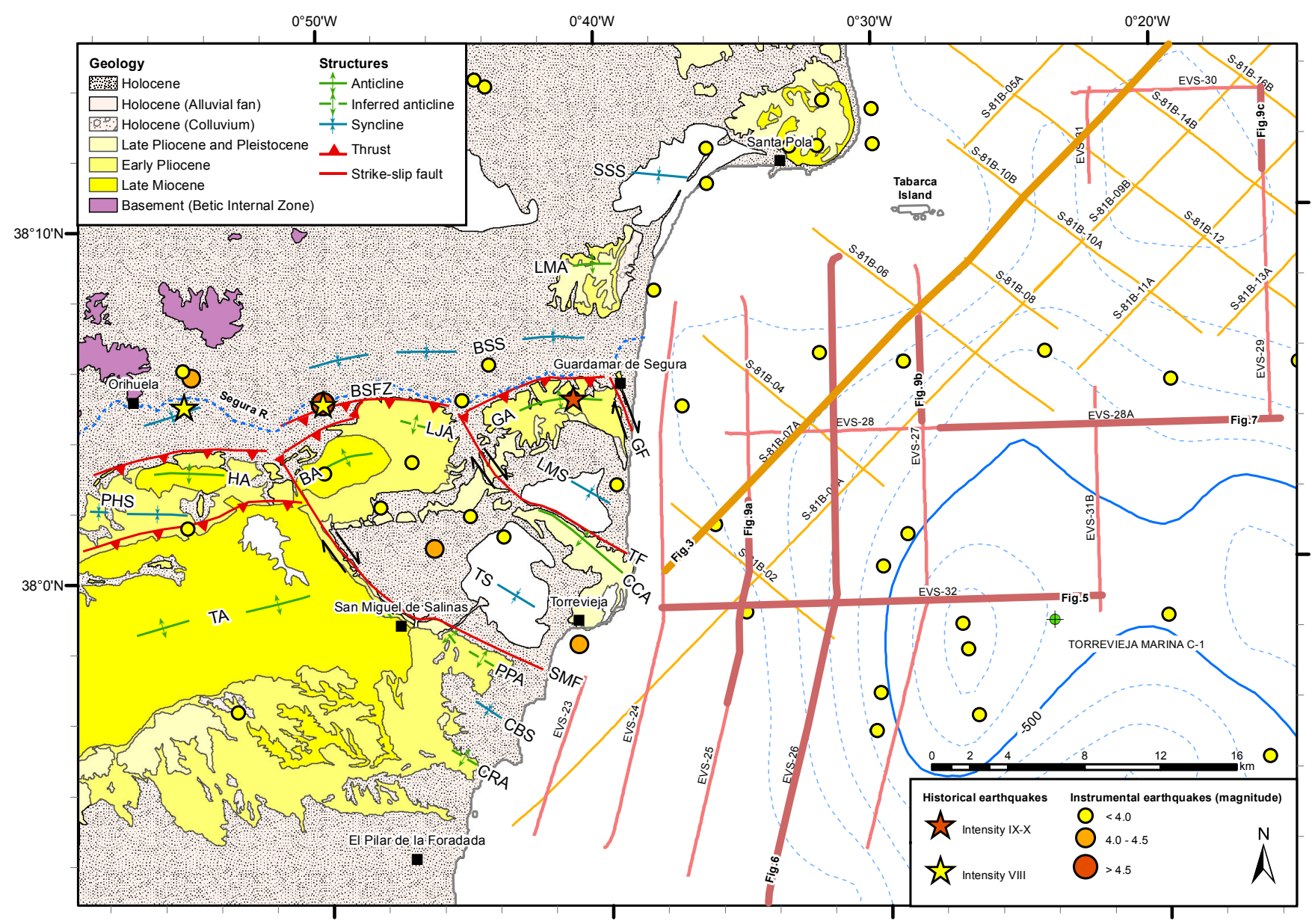

Fig. 2. Bathymetric (dashed blue lines with contour interval $100 \mathrm{~m}$ ) and geological (Alfaro et al., 2002a, b) map of the Bajo Segura basin. Stars and dots show the historical and instrumental epicenters, respectively (IGN, 2011). Orange lines correspond to commercial MCS profiles (survey S-81B 25/81; Archivo Técnico de Hidrocarburos, 2012) and pink lines to SCS sparker profiles obtained during the EVENTSHELF cruise. Fault kinematics refers to Upper Neogene. Faults: BSFZ: Bajo Segura fault zone; GF: Guardamar fault; SMF: San Miguel de Salinas fault; TF: Torrevieja fault. Folds: BA: Benejúzar anticline; BSS: Bajo Segura syncline; CBS: Cala del Bosque syncline; CCA: Cabo Cervera anticline; CRA: Cabo Roig anticline; GA: Guardamar anticline; HA: Hurchillo anticline; LJA: Lomas de la Juliana anticline; LMA: La Marina anticline; LMS: La Mata syncline; PHS: Pino Hermoso syncline; PPA: Punta Prima anticline; SSS: Salinas de Santa Pola syncline; TA: Torremendo anticline; TS: Torrevieja syncline.

\section{Geodynamic and seismicity settings of the Bajo Se- gura basin}

\subsection{The onshore Bajo Segura basin}

The Bajo Segura basin is located in the Eastern Betic Cordillera (SE Spain), in the northern terminal splay of the EBSZ and extends eastwards into the Mediterranean Sea (Figs. 1 and 2). The basin is infilled by a succession of Upper Miocene to Quaternary sedimentary units that can be summarized (Montenat, 1977), from bottom to top, as the following: (a) Upper Miocene (Upper Tortonian) shallow marine (conglomerates and sandstones), slope and pelagic facies (marls and turbidites); (b) Upper Miocene (Late TortonianMessinian) slope and pelagic basin facies topped by shal- low marine facies (evaporites, sandstones and coral reefs); (c) Pliocene unit comprising (Montenat, 1977), from bottom to top, the following: Hurchillo marls formation (pelagic marine facies), Rojales sandstone formation (coastal and shallow shelf facies), variegated lutite formation (river floodplain facies), and Segura conglomerates formation (fluvial channelized facies); and (d) Quaternary units, about $30 \mathrm{~m}$ thick, with the upper $20 \mathrm{~m}$ dated between $14570 \mathrm{yr} \mathrm{BP}\left({ }^{14} \mathrm{C}\right.$ age; Soria et al., 1999) and the present, and characterized by isolated outcrops of Pleistocene alluvial fans, marine terraces and a cover of unconsolidated sediments deposited along the present Segura River valley (Fig. 2). The Upper MioceneQuaternary sedimentary cover overlies a basement forming part of the Internal Zone of the Betic Cordillera (Triassic calcareous metamorphic rocks of the Alpujarride complex). 
From the Upper Miocene to the present, the Bajo Segura basin area has been distinguished by a transpressive regime (Silva et al., 1993; Alfaro et al., 2002a, b), with a NNWSSE compressive stress field. In this geodynamic setting, the basement and the Upper Miocene to Quaternary sedimentary cover of the Bajo Segura basin have been folded and faulted (Fig. 2). This basin is bordered by two main faults: the Crevillente fault (Focault, 1974) to the north (Fig. 1), and the BSFZ (Montenat, 1977) to the south, both running approximately ENE-WSW. The BSFZ is characterized by several ENE-WSW blind thrusts that offset the Triassic basement of the Internal Zone and fold the Upper Miocene to Quaternary sedimentary cover (Montenat, 1977; Bousquet, 1979; López Casado et al., 1987; Somoza, 1993; Taboada et al., 1993; Alfaro, 1995; Alfaro et al., 2002a, 2012). The activity of these blind thrusts has produced an anticlinorium constituted by several north verging folds (Fig. 2), the most important being the Torremendo, Hurchillo, Benejúzar, Lomas de la Juliana and Guardamar anticlines, and the Bajo Segura, Torrevieja and La Mata synclines. Other secondary folds, hectometric in scale, are also present in the basin. The folds are generally gentle or open with limbs usually dipping less than $30^{\circ}$, although strata of the Pliocene Segura conglomerate formation are sub-vertical in the northern limb of the Hurchillo anticline (Alfaro et al., 2002a). These active growth folds are interpreted as the result of several imbricated ENE-WSW blind thrusts limited by NW-SE San Miguel de Salinas (SMSF), Torrevieja (TF) and Guardamar dextral transfer faults (Alfaro et al., 2002a). The age of formation of the folds was established from the analysis of successive progressive unconformities in the fold limbs, and it is not synchronous along the entire basin. For instance, the E-W folds, such as La Marina and Santa Pola anticlines, initiated their activity during the Upper Miocene, whereas the NW-SE folds, such as the Cabo Cervera anticline and the Torrevieja syncline, became active during the Pliocene (Alfaro et al., 2002a; Giménez et al., 2009). A vertical uplift rate of about $0.2 \mathrm{~mm} \mathrm{yr}^{-1}$ has been calculated comparing high-precision leveling measurements obtained in 1976, 1997 and 2003 along a $30 \mathrm{~km}$ profile cutting across the BSFZ (Giménez et al., 2009). This result confirms the recent activity of the faults and folds in the Bajo Segura basin.

\subsection{The offshore study area}

The offshore Bajo Segura basin is characterized by a wide shelf with an average width of $15 \mathrm{~km}$ and a smooth depression in its center (Fig. 2). The maximum depth in the area is around $700 \mathrm{~m}$ and is located to the east of the central depression. Tabarca island is located in the north of the basin where the shelf is wider. The integration of seismic reflection profiles, gravimetry, seismicity, cores and outcrop data showed that the compressive active structures described onshore propagate towards the east into the Mediterranean Sea (Alfaro et al., 2002b; Perea et al., 2010). The main feature already known and described in the offshore is the Tabarca anticline ridge (Fig. 3), which extends around $80 \mathrm{~km}$ from the coast in an ENE-WSW direction and is 20 to $30 \mathrm{~km}$ wide (Alfaro et al., 2002b). This ridge is bounded by thrust faults (GF4 and GF5, to the south, and SPF2, to the north, Fig. 3) verging in opposite directions and folding the Upper Miocene unit. The southern thrusts dip to the north and produce the uplift of the Guardamar high, whereas the northern thrusts dip to the south and raise the Santa Pola high. In the middle of the Tabarca anticline ridge is the BSFZ, which is composed of thrust faults that dip to the south and fold the Upper Miocene unit. To the north and south of this anticline ridge, there are the Alicante and Torrevieja growth synclines, respectively. These two synclines have operated as subsided zones since the start of the folding (Alfaro et al., 2002b). Along the Tabarca anticline ridge are secondary active anticlines and synclines. These synclines are filled with syntectonic sediments that reach the Quaternary.

\subsection{Instrumental and historical seismicity}

The Bajo Segura basin shows moderate seismic activity marked by earthquakes with magnitudes lower than 4.0 (Fig. 2). Nevertheless, there have been some earthquakes with higher magnitudes, such as the 1979 San Miguel de Salinas earthquake ( $\mathrm{mb} 4.2$ ), the composed 1919 Jacarilla earthquake characterized by two events (mb 5.2 and 5.1) and the 2003 east Torrevieja earthquake ( $\mathrm{mb} 4.0$ ). The seismicity observed in the onshore basin seems to be related to the main structures such as BSFZ, SMSF and TF faults. In addition, significant seismic activity has been recorded offshore. Given the uncertainty in the location of this seismicity, it is difficult to associate the earthquakes to some specific structures. However, a group of earthquakes shows an E-W strike coinciding with the offshore prolongation of the BSFZ (Fig. 2).

The historical seismic catalog (IGN, 2011) shows that the area has been affected by some destructive earthquakes, such as the $1048\left(I_{\mathrm{EMS} 98}=\mathrm{X}\right)$, the $1482\left(I_{\mathrm{EMS} 98} \mathrm{VIII}\right)$ and the 1484 ( $I_{\text {EMS98 }}$ IX) in Orihuela, the 1523 ( $I_{\text {EMS98 }}$ VIII) in Guardamar del Segura, the 1746 ( $I_{\mathrm{EMS} 98}$ VII) in Rojales and the $1802,1828,1837,1867$ and 1909 , all of them ( $I_{\mathrm{EMS} 98}$ VII) in Torrevieja (Bisbal, 1984; Giner et al., 2003; IGN, 2011). Nevertheless, the most destructive earthquake to have struck the Bajo Segura basin and the SE Iberian Peninsula was the 1829 Torrevieja earthquake ( $\left.I_{\mathrm{EMS} 98} \mathrm{IX}-\mathrm{X}\right)$, which caused 389 fatalities and devastated Torrevieja and other small towns along the Segura River valley (Rodríguez de la Torre, 1984; Muñoz and Udías, 1991; Albini and Rodríguez de la Torre, 2001; Martínez Solares and Mezcua, 2002). 


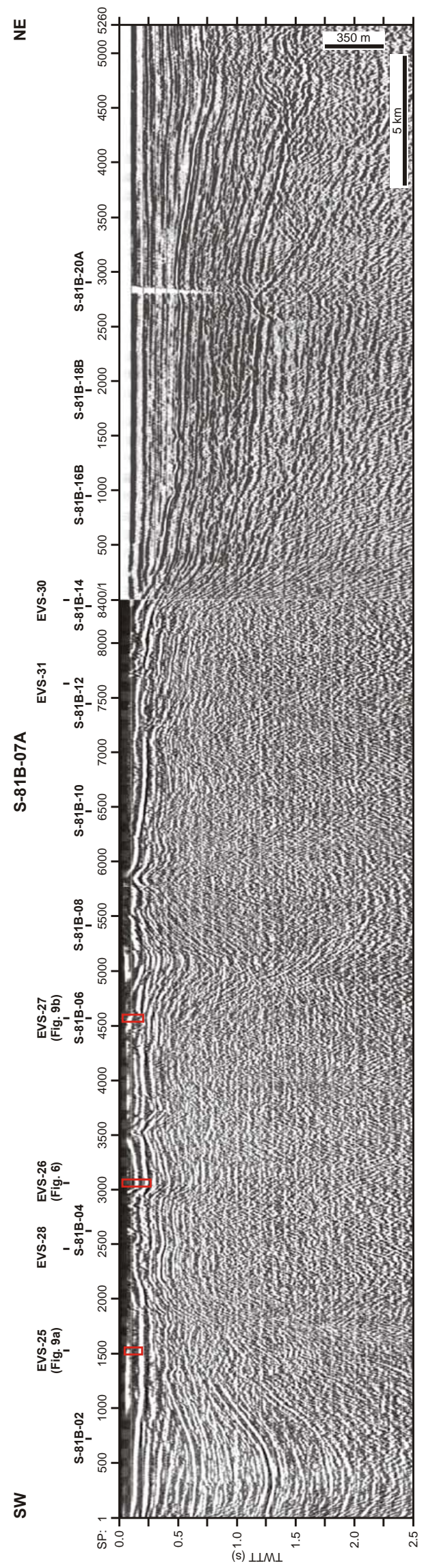

www.nat-hazards-earth-syst-sci.net/12/3151/2012/

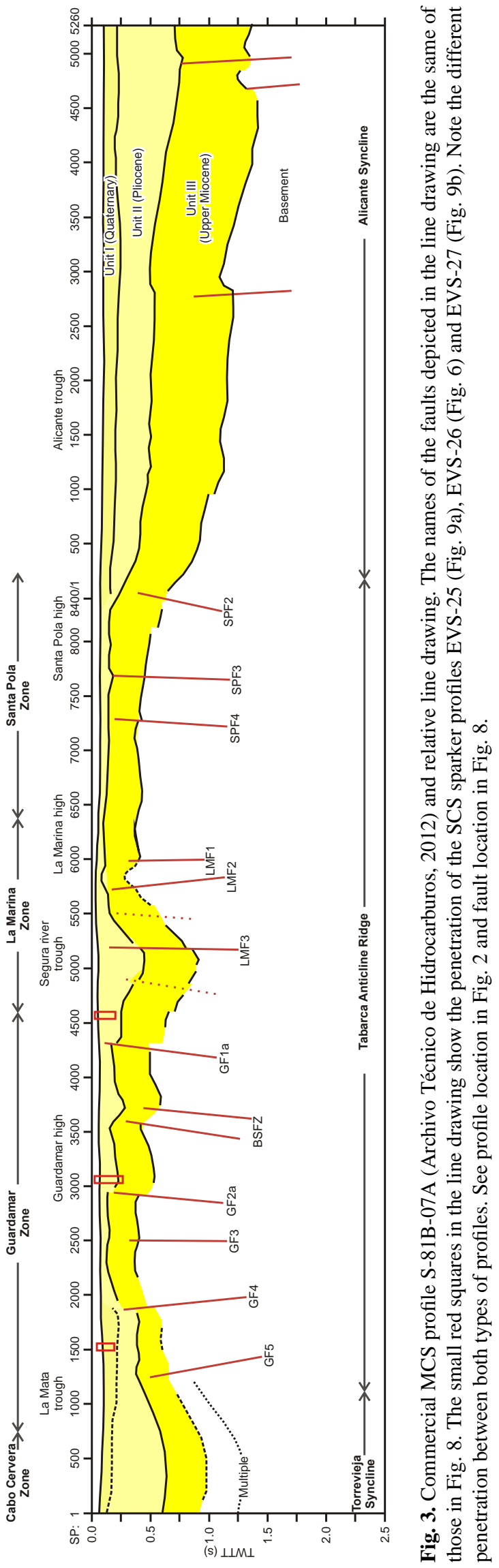

Nat. Hazards Earth Syst. Sci., 12, 3151-3168, 2012 


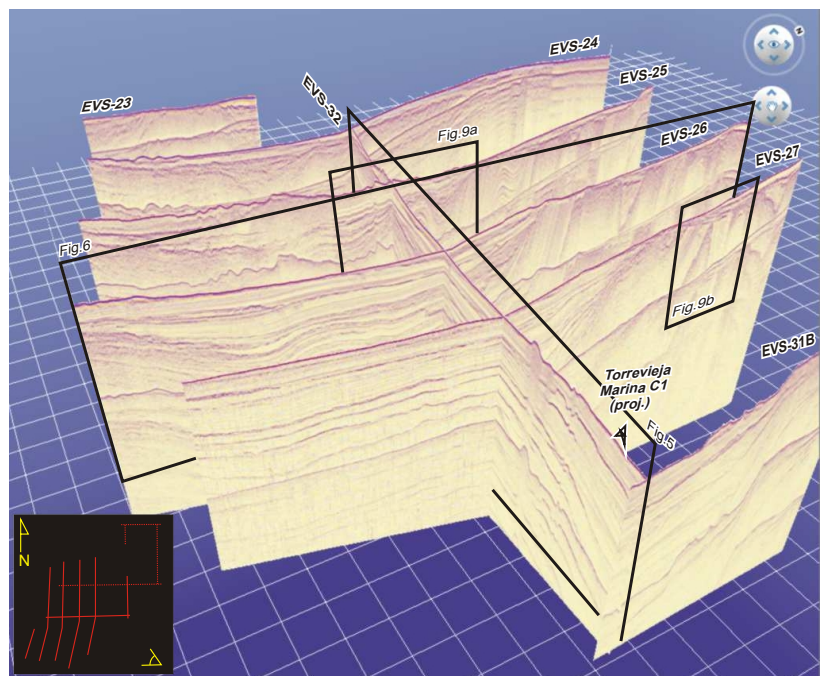

Fig. 4. 3-D view from the SE of the SCS sparker profiles obtained during the EVENT-SHELF cruise on the Bajo Segura offshore basin. Note the shallowness of the Neogene basement (almost transparent seismic facies) to the north of the basin and how the Quaternary sedimentary basin (continuous reflector facies) thickens to the east and onlaps the basement to the north. Figures 5, 6, 9a and $9 \mathrm{~b}$ are located in this figure. Lower-left inset; red lines: displayed profiles; dotted red lines: not displayed profiles; yellow symbol: point of view of the 3-D view. See location of profiles in Fig. 2 .

\section{Data and methods}

In the offshore Bajo Segura basin during the EVENT-SHELF cruise, we sought to explore the prolongation towards the continental shelf of the onshore structures (faults and folds) active in the Quaternary and to provide evidence of their recent activity. To this end, a SCS sparker system was installed onboard the R/V García del Cid (CISC) in order to obtain high-resolution profiles to investigate seafloor ruptures and the shallow sub-surface structure. The source was a sparker GEO-SPARK $6 \mathrm{~kJ}$ manufactured by GEORESOURCES BV, specially designed to favor high frequencies. The triggering was every $2 \mathrm{~s}$ and the source used ranged between 4 and $6 \mathrm{~kJ}$. The receiver consisted of a 9-m-long, 24hydrophone single-channel streamer. The seismic signal was recorded by the Geo-trace acquisition system with a sampling rate of $100 \mu$ s and a length of the record between 1.5 and $2.0 \mathrm{~s}$ TWTT, allowing up to $30 \mathrm{~cm}$ of vertical resolution and $400 \mathrm{~m}$ of penetration below the seafloor surface. Postprocessing consisted of change of polarity (the system uses a negative electric discharge instead of a positive pulse), debias, high-pass filter of $300 \mathrm{~Hz}$ and a low-pass band filter of $1400 \mathrm{~Hz}, \mathrm{AGC}(10 \mathrm{~ms}$ window applied to the whole trace), gain, spherical divergence correction and a swell filter. Ten SCS sparker profiles (EVS-23 to EVS-32) were obtained, most of them being perpendicular to the onshore structures
(Figs. 2 and 4). The signal was recorded in a SEG-Y format and later analyzed on SMT Kingdom Suite software.

Commercial multichannel seismic (MCS) profiles were obtained and processed by the EXXON Company in 1982 during the S-81B (25/81) survey along the Alicante offshore basin (Archivo Técnico de Hidrocarburos, 2012). The source used comprised a tuned array of 6 clusters of 6 airguns, towed

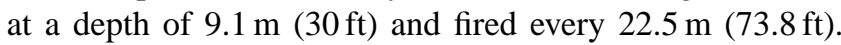
Seismic data were recorded at $4 \mathrm{~ms}$ sampling interval, record length of $5 \mathrm{~s}$ TWTT, using a 203-channel Teledyne streamer towed at a depth of $10.6 \mathrm{~m}(35 \mathrm{ft})$. The seismic processing flow included exponential gain correction and pre-stack deconvolution (160 ms operator length). Later, CMP sorting, velocity analysis, NMO correction and post-stack deconvolution ( $256 \mathrm{~ms}$ operator length) were applied. Then, the profiles were post-stack wave equation time migrated. Finally, MCS sections were time variant band-pass and time scaled filtered.

The multibeam swath-bathymetry was obtained at the same time as the SCS sparker profiles. The used multibeamechosounder was an Elac Nautik SeaBeam 1050D, emitting a frequency of $180 \mathrm{kHz}$. Given that the objective of the cruise was the acquisition of SCS sparker profiles, the bathymetric coverage was limited to the areas crossed during the seismic survey. Thus, about $276 \mathrm{~km}$ with an average width of $300 \mathrm{~m}$ were recorded during the cruise. Nevertheless, small-scale morpho-structures such as sloping ramps and rocky reliefs up to $4 \mathrm{~m}$ high were found in the study area. However, a highresolution bathymetric map is necessary to understand the significance of these morpho-structures and the active processes that occur in the area.

\section{Seismo-stratigraphy and structures of the offshore Bajo Segura basin}

\subsection{Seismo-stratigraphic units}

The commercial MCS and SCS sparker profiles enabled us to distinguish seismo-stratigraphic units at different resolutions and depth intervals.

In the commercial MCS profiles three seismo-stratigraphic units were identified (Fig. 3), units I, II and III. Unit I, from top to bottom, is mainly preserved in the depressed areas with a maximum thickness of $0.2 \mathrm{~s}$ TWTT. It has sheet drape geometry and does not show internal reflectors at this resolution. Unit II has regional distribution and sheet drape geometry. Internal reflectors are roughly continuous and parallel with medium-to-high amplitude and low frequency. Divergent reflections can be observed close to the active zones. In the uplifted areas, reflectors from the top of unit II are eroded and onlap the lower unit III. Unit III is recognized in all the profiles. It shows sheet to sheet drape geometry with parallel and roughly continuous reflectors of high-to-medium amplitude and medium-to-low frequency. Comparison with the 

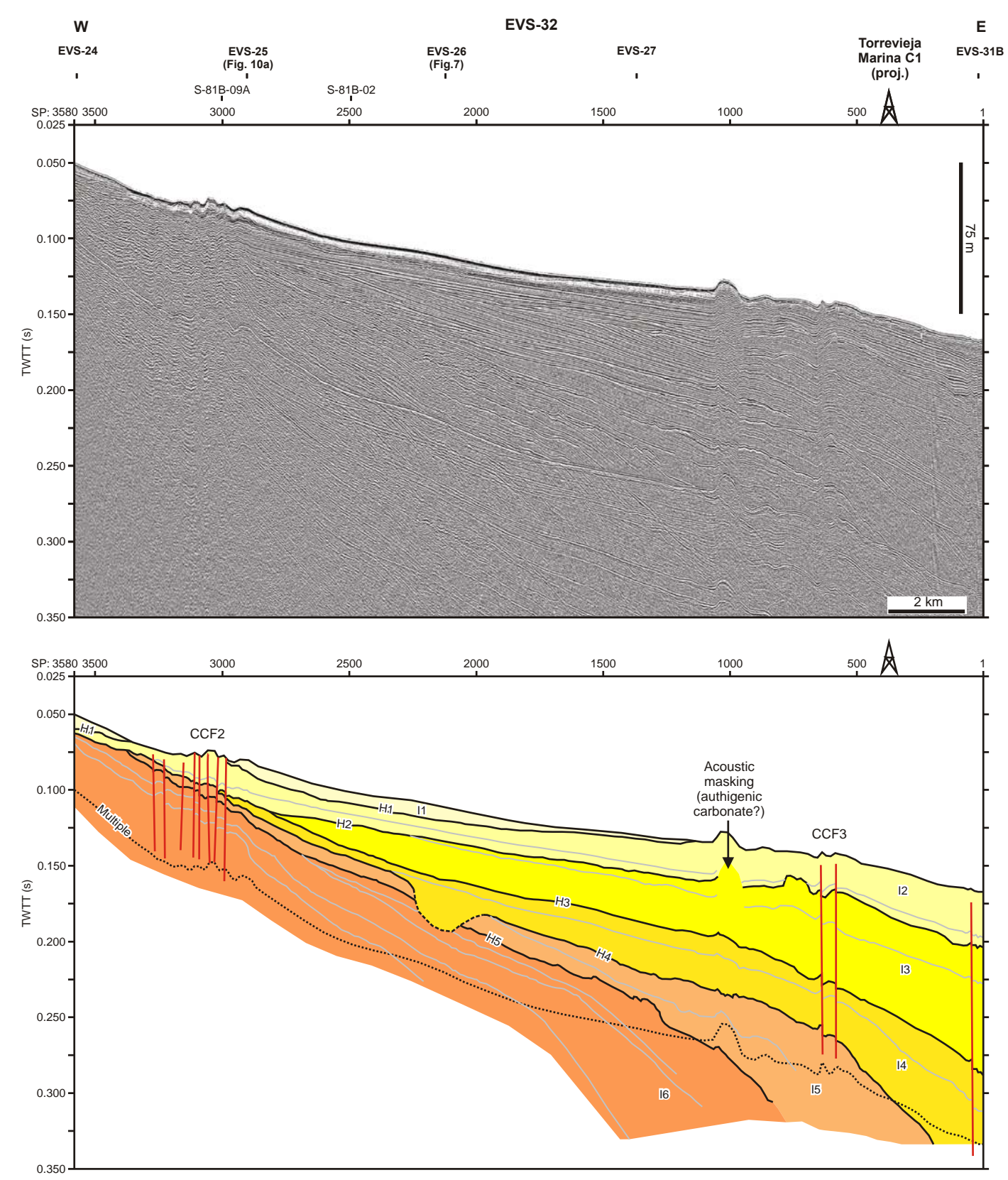

Fig. 5. SCS sparker profile EVS-32 and relative line drawing showing the identified seismo-stratigraphic units and structures. Note that the CCF2 (Fig. 8) fault zone is offsetting the seafloor surface, thus demonstrating the recent activity on this fault zone. Around shot point (SP) 1000, there is an acoustic masking facies that could be related to authigenic carbonates (Lo Iacono et al., 2011). The position of the Torrevieja Marina C-1 well is projected. See profile and well location in Figs. 2 and 4.

work of Alfaro et al. (2002b) shows that units I and II are equivalent to their Pliocene-Quaternary unit, and unit III to their Upper Miocene unit. These authors established the age of these units based on a correlation with commercial wells located in the area (one of them the Torrevieja Marina C-1 described below and located in Fig. 2) and also with the geological units observed in the onshore basin and explained briefly in Sect. 2.1.
On the SCS sparker profiles (Figs. 2 and 4), up to six units (I1 to I6) have been identified, bounded by five horizons (H1 to H5) that correspond to regional erosion surfaces (Figs. 5, 6 and 7). Units I1 to I6 are divided into several subunits limited by minor discordances (gray lines in Figs. 5, 6 and 7). A total of fifteen subunits were differentiated. Commonly, reflectors are continuous and parallel with a decreasing amplitude and frequency in depth. In general, the deeper zones of the basin show concordant geometry and the shallow areas reveal 


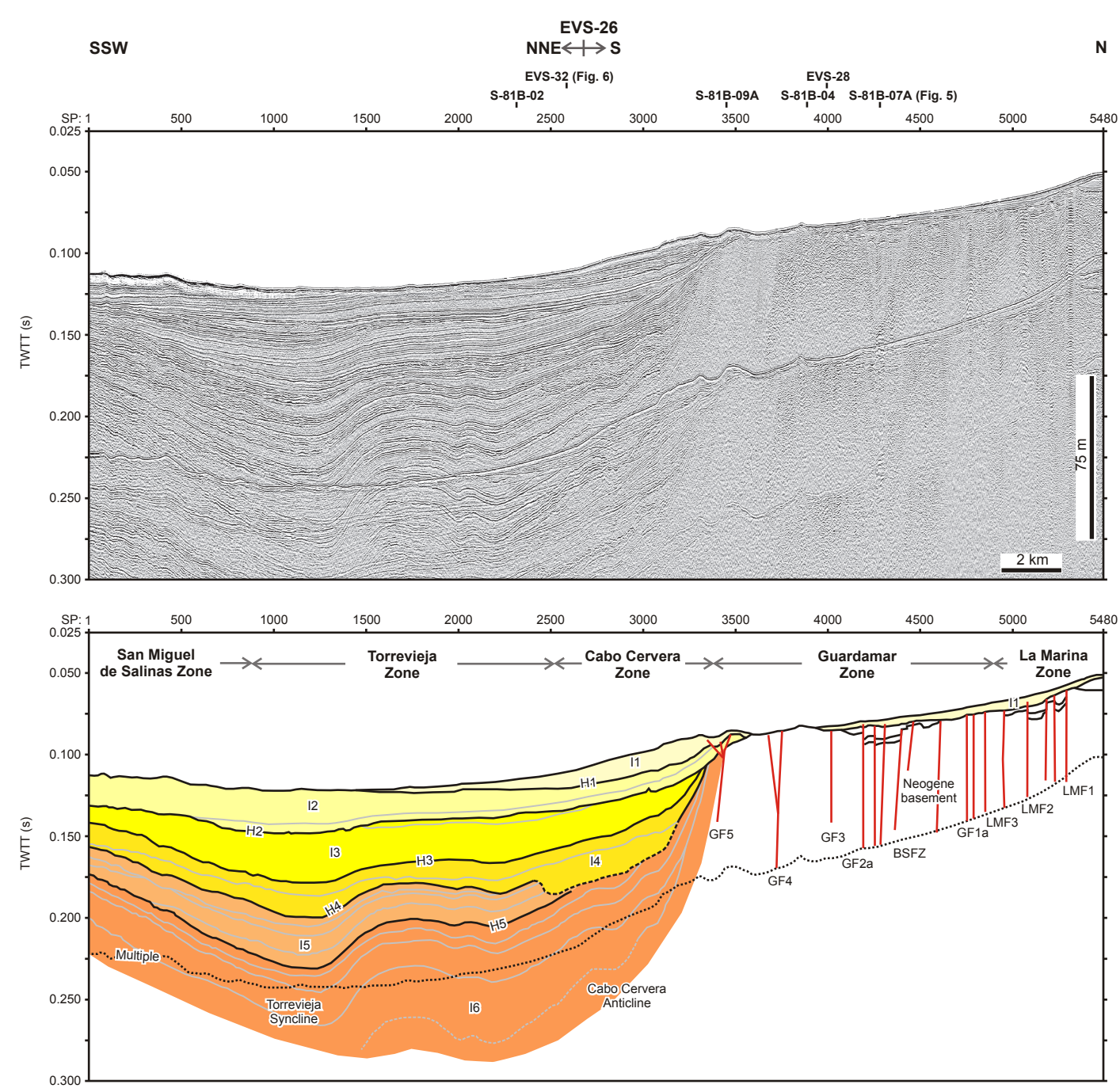

Fig. 6. SCS sparker profile EVS-26 and relative line drawing showing the seismo-stratigraphic units and structures. Note how the folding affects unit I3 and some reflectors at the base of unit I2 in the Torrevieja zone and that some faults affect unit I1 in Guardamar and La Marina zones. See location of profile in Figs. 2 and 4.

erosional truncation, although toplaps can occur (Figs. 4, 5, 6 and 7). The base of the units is generally distinguished by onlapping geometry in the uplifted zones. This geometry progressively becomes concordant and, finally, downlaps towards the center of the basin.

The Torrevieja Marina C-1 commercial exploration well is located close to the EVS-32 SCS sparker profile (Figs. 2, 4 and 5). This well was operated by ENIEPSA in November 1978, and the recovered core was $578 \mathrm{~m}$ long (Lanaja et al., 1987). Three units were recognized in the well (Lanaja et al., 1987), from top to bottom: (a) $386 \mathrm{~m}$ of calcareous clay unit with fine sand layers, Quaternary in age; (b) $109 \mathrm{~m}$ of clay unit with fine layers of sand and limestone at the base, Upper Pliocene to Quaternary in age; and (c) $83 \mathrm{~m}$ of dolomite and dolomite limestone unit, Upper Pliocene in age. The sedimentary thickness imaged in the SCS sparker profile EVS-32 above the multiple (0.152 s TWTT) on the projection of Torrevieja Marina C-1 well (shot point 360) is around $120 \mathrm{~m}$ (velocity of seismic waves between 1500 and $1600 \mathrm{~m} \mathrm{~s}^{-1}$ ) and corresponds to the Quaternary unit in the well. Therefore, units I1 to I5, and most probably I6, must be Quaternary in age. Comparison of the SCS sparker profiles with commercial MCS profiles shows that units I1 to I6 (Figs. 5, 6 and 7) coincide to the upper unit I (Fig. 3). Thus, unit I must be Quaternary in age.

Unit I1 is the upper unit distinguished in the offshore basin. This unit becomes thinner and discontinuous from the coastline towards the basin, and its lower boundary corresponds to horizon $\mathrm{H1}$, which is a regional erosional surface (Figs. 5, 6 and 7). Close to the coast, unit I1 attains a thickness of $15 \mathrm{~m}$. Onshore, the last $20 \mathrm{~m}$ of the Quaternary unit were deposited during the last $14570 \mathrm{yr}$ BP. Thus, unit I1 


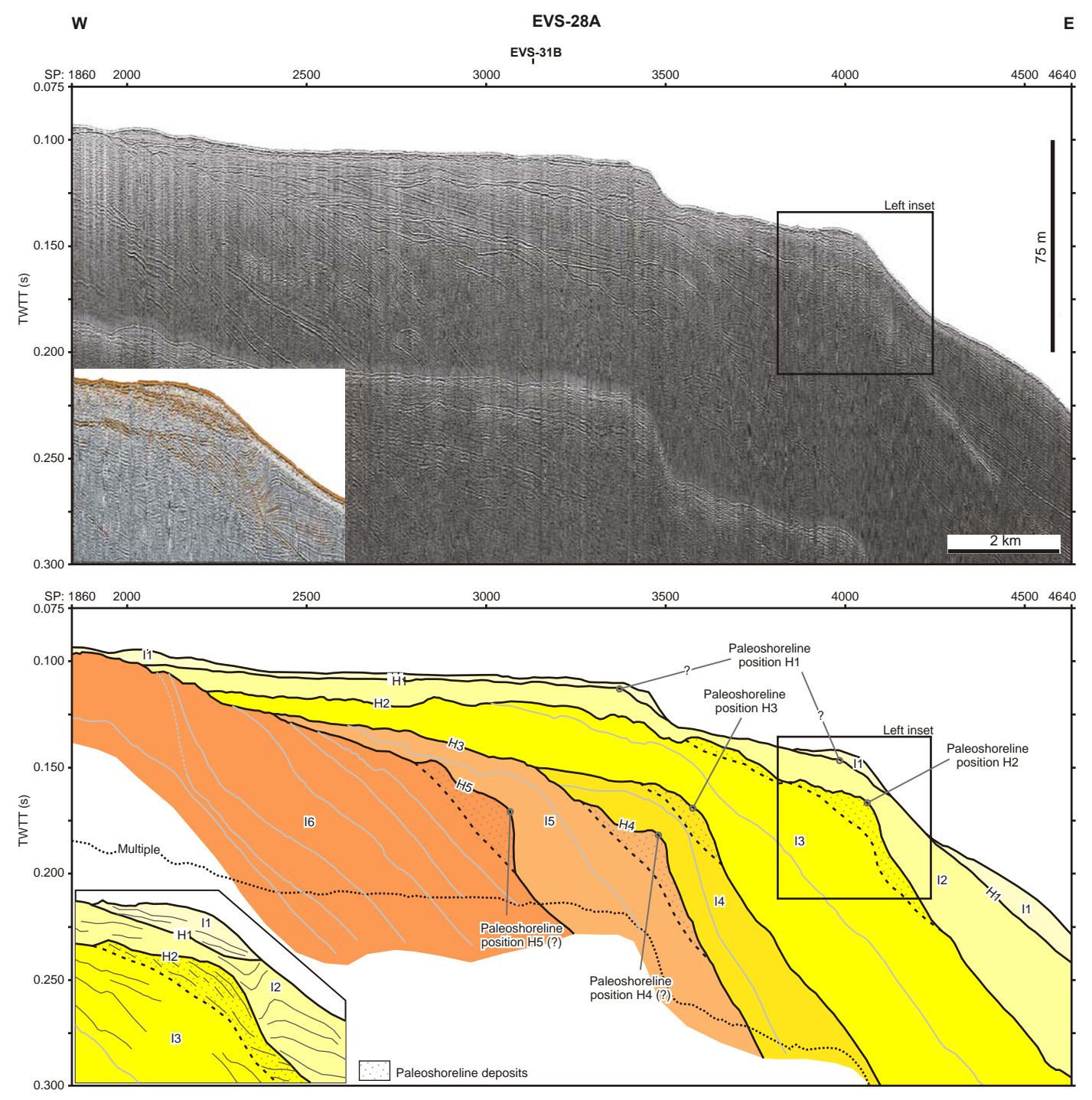

Fig. 7. SCS sparker profile EVS-28A and relative line drawing showing the seismo-stratigraphic units. Note the presence of large erosional surfaces that in some cases end in ancient paleoshorelines indicated by the change in reflector slope and by the probable presence of shoreline deposits (detail in the left inset). These surfaces were used to determine the age of the seismic horizons H1 to H5. See profile location in Fig. 2.

must be the continuation of the Quaternary onshore unit and it may be the offshore sedimentary unit deposited since the last glacial maximum (LGM). Accordingly, H1 may be related to the last global sea level lowstand, which is associated with Marine Isotopic Stage 2 (MIS2) and dates $20 \pm 5 \mathrm{ka}$. In some SCS sparker profiles, this erosional surface ends in an abrupt change in slope (Fig. 8). This might correspond to the position of the LGM paleoshoreline, which at present is located approximately at $106 \mathrm{~m}$ below the present sea level (b.p.s.l.) (considering that the velocity of seismic waves propagation on sea water is $1500 \mathrm{~m} \mathrm{~s}^{-1}$ and in the first hundreds of meters of the sedimentary layer $1600 \mathrm{~m} \mathrm{~s}^{-1}$ ). In the Gulf of Lions, the LGM paleoshoreline was placed between 102 and $107 \mathrm{~m}$ b.p.s.l. (Rabineau et al., 2006). These results are in agreement with the observations made in the Bajo Segura basin and support the hypothesis that $\mathrm{H} 1$ is the erosional surface developed during the LGM lowstand.

Given that horizon H1 could be attributed to the LGM sea level lowstand, it is reasonable to assume that the other horizons, H2 to H5, correspond to other global sea level lowstands and could therefore be associated with different MIS (e.g. Rabineau et al., 2006; Ridente et al., 2008). Nevertheless, it should be noted that the present evolution of the Bajo Segura basin is controlled by Quaternary active structures. Comparison with other zones located in tectonically passive environments is therefore not straightforward. To avoid the effects of tectonic deformation, the following depth calculations of probable ancient paleoshorelines were made in the 


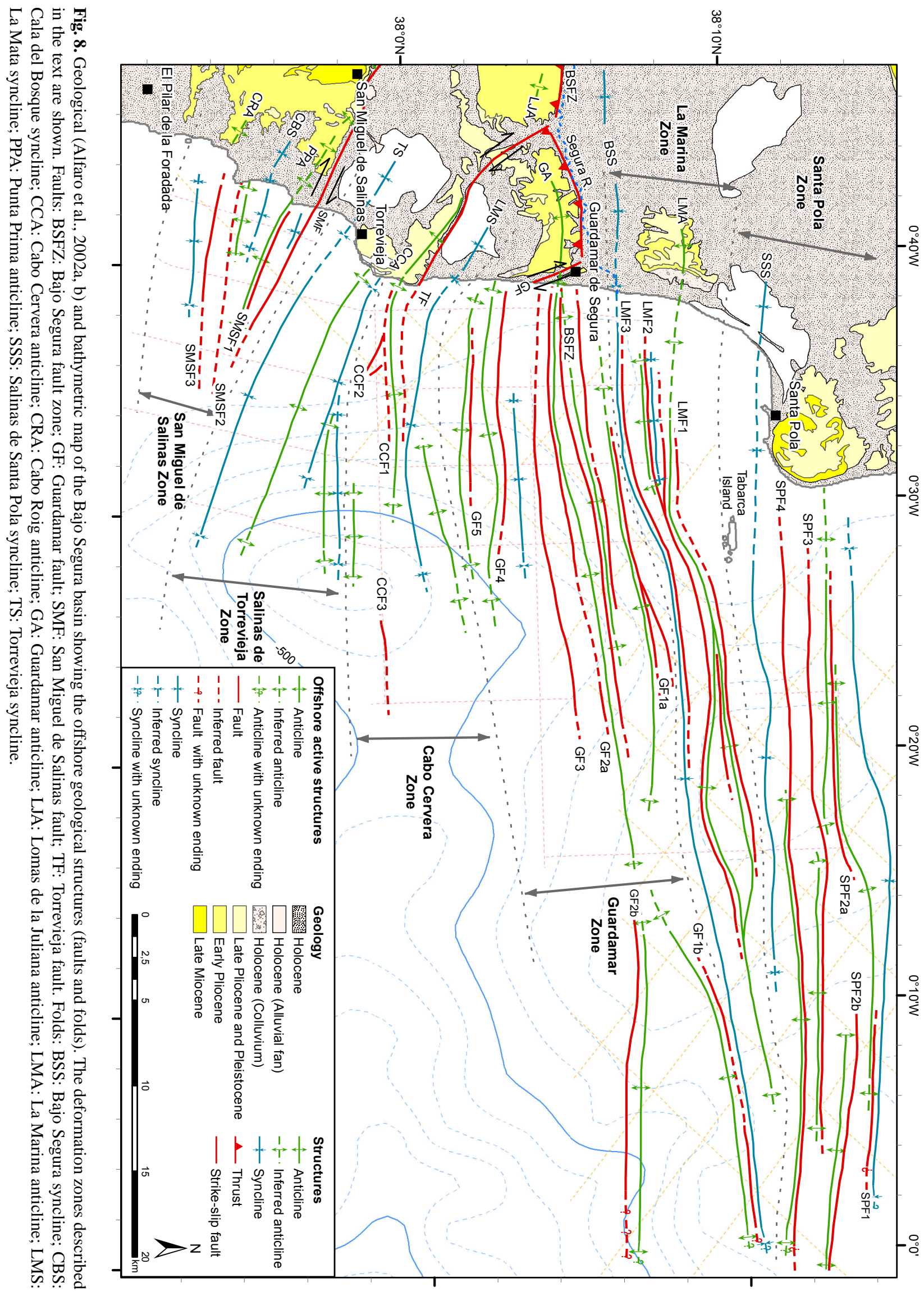


E-W profiles that are parallel to the main active structures (Figs. 5 and 7).

Horizon $\mathrm{H} 2$ is located at the base of unit I2 (Figs. 5, 6 and 7) and is interpreted as a regional erosional surface. In line with the assumptions made to date $\mathrm{H} 1, \mathrm{H} 2$ might also be ascribed to a global sea level lowstand. In profile EV28A, the erosional surface ends in an abrupt change in slope where some possible paleoshoreline deposits could be identified (Fig. 7). The depth of this ancient paleoshoreline is $121 \mathrm{~m}$ b.p.s.l., $15 \mathrm{~m}$ below H1. In the Gulf of Lions, the paleoshoreline associated with MIS6 is located $16 \mathrm{~m}$ below MIS2 (Rabineau et al., 2006). Because of the similar values obtained in both areas, it may be assumed that $\mathrm{H} 2$ developed during MIS6 (135 $\pm 5 \mathrm{ka})$. Minor discontinuities in unit I2 could correspond to (a) minor sea level oscillations similar to those in the Adriatic Sea that have been attributed to different stages of MIS5 (Ridente et al., 2008), or (b) tectonic activity.

Horizon H3 is located at the base of unit I3 (Figs. 5, 6 and 7). As in the case of the aforementioned horizons, $\mathrm{H} 3$ is a regional erosional surface with an associated ancient paleoshoreline located at $125 \mathrm{~m}$ b.p.s.l., $4 \mathrm{~m}$ below $\mathrm{H} 2$ and closer to the present shoreline (Fig. 7). Given its regional character and after comparison with $\mathrm{H} 1$ and $\mathrm{H} 2, \mathrm{H} 3$ could also be correlated with an older global sea level lowstand. In the Gulf of Lions, the difference between the second and the third discontinuities ascribed to sea level drops is also $4 \mathrm{~m}$, the latter discontinuity being assigned to MIS8.2 (Rabineau et al., 2006). Considering this and the similarities to the other horizons, H3 could correspond to MIS8.2 (247.6 $\pm 5 \mathrm{ka})$.

The fourth horizon is $\mathrm{H} 4$ located at the base of unit $\mathrm{I} 4$ (Figs. 5, 6 and 7). This horizon also seems to be a regional erosional surface. The uncertainty is related to the fact that the zones where it can be best observed are uplifted and folded. Nevertheless, an ancient paleoshoreline related to $\mathrm{H} 4$ was identified approximately at $144 \mathrm{~m}$ b.p.s.l. (Fig. 7). Because of the similarities to $\mathrm{H} 1, \mathrm{H} 2$ and $\mathrm{H} 3$, horizon $\mathrm{H} 4$ could have been formed during a global sea level lowstand corresponding to MIS10 ( $341 \pm 5 \mathrm{ka})$.

Finally, the last regional discontinuity is horizon H5, which is located at the base of unit I5 (Figs. 5, 6 and 7). This is the last and the deepest regional erosional surface observed in the SCS sparker profiles. A probable ancient paleoshoreline was identified between 130 and $168 \mathrm{~m}$ b.p.s.l. (Fig. 7). This large range in the depth of the paleoshoreline is attributed to the difficulty of observing it in areas without deformation. Compared with the other horizons, H5 could also be related to a global sea level lowstand and assigned to MIS12 (434 $\pm 5 \mathrm{ka})$.

\subsection{Offshore faults and fold systems}

As stated above, the Tabarca anticline ridge is the main structure in the offshore Bajo Segura basin (Fig. 3). The analysis of the commercial MCS and SCS sparker profiles that cross the area enabled us to identify different structures (faults and folds) that produced the uplift of the Tabarca anticline ridge. Most of the structures trend WSW-ENE to W$\mathrm{E}$ and have a compressive component in their kinematics, which is in agreement with the present regional stress field. The geological structures were grouped into six deformation zones coinciding with the main structures observed onshore and bounded by regional synclines. From north to south, these deformation zones are (a) Santa Pola zone, (b) La Marina zone, (c) Guardamar zone, (d) Cabo de Cervera zone, (e) Salinas de Torrevieja zone, and (f) San Miguel de Salinas zone. These structures were correlated between the different commercial MCS and SCS sparker profiles and with the onshore geology (Fig. 8).

The Santa Pola zone is located in the north of the study area (Fig. 8). This deformation zone is bounded to the north and south by two synclines with an E-W direction that extends at least $50 \mathrm{~km}$ from the coastline into the sea. The northern syncline, which is a prominent regional fold that bounds the Tabarca ridge towards the north, marks the beginning of the Alicante syncline (Fig. 3). The southern syncline is a smooth fold that could be correlated with the Salinas de Santa Pola syncline observed onshore (Montenat, 1977; Somoza, 1993; Alfaro, 1995), although with some uncertainty. Between these two synclines is the Santa Pola high (Fig. 3), an E-W trending smooth ridge comprising narrowly spaced anticlines associated with faults with the same direction. The faults in the north dip slightly towards the south, whereas in the center of the zone these are sub-vertical (Figs. 3 and 9c). The commercial MCS profiles show that these faults affect unit III, but whether they disturb unit II is not clear. Nevertheless, the SCS sparker profiles show that the faults clearly offset reflectors under horizon H2 (fault SPF3 in Fig. 9c), indicating their Quaternary activity.

South of the Santa Pola zone, La Marina zone (Fig. 8) has a WSW-ENE direction, extends at least $50 \mathrm{~km}$ and is located between two synclines: the Salinas de Santa Pola to the north, and the marine continuation of the onshore Bajo Segura syncline (Montenat, 1977; Taboada et al., 1993; Alfaro et al., 2002a, b; Giménez et al., 2009) to the south (Fig. 3), which continues along the offshore basin. The main faults are localized to the south and north of those synclines, respectively (Fig. 3). Associated with faults LMF1 and LMF2 is an anticline which in some areas has a double hinge, producing a small syncline in between. Towards the east, this anticline probably joins the southern anticline of the Santa Pola zone, leading to the disappearance of the Salinas the Santa Pola syncline. The faults dip slightly towards the central part of the zone. In the commercial MCS profiles, the faults affect unit III, and fault LMF3 affects unit II (Fig. 3). The higher resolution of the SCS sparker profiles shows that these faults are sealed by horizon H1, although in some places this horizon might be displaced (Fig. 6). The anticlines fold horizon $\mathrm{H} 2$ and probably fold $\mathrm{H} 1$. 


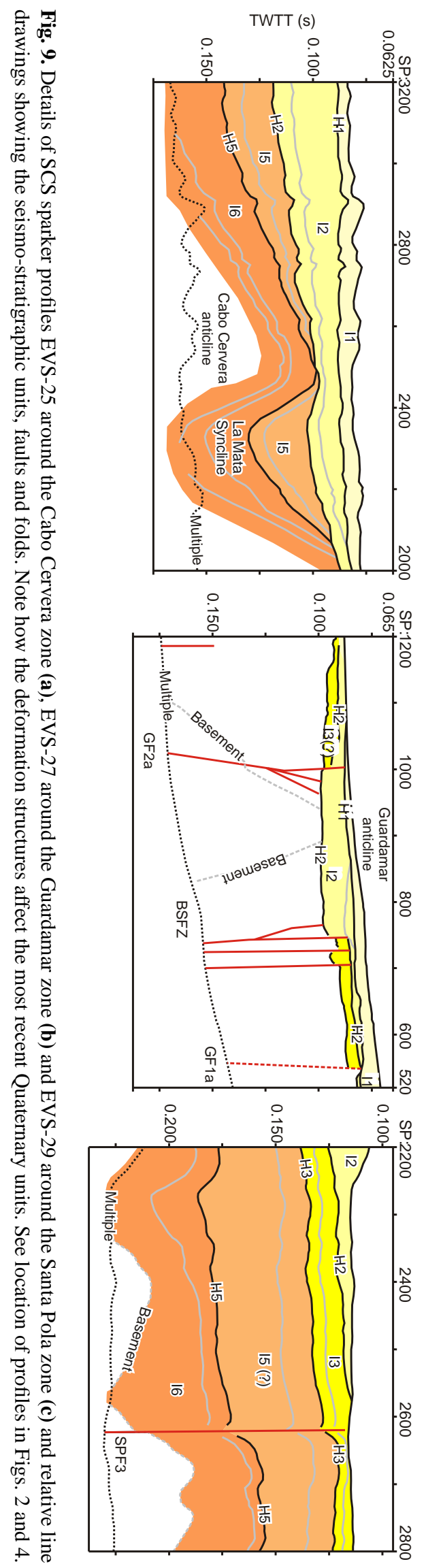

Nat. Hazards Earth Syst. Sci., 12, 3151-3168, 2012

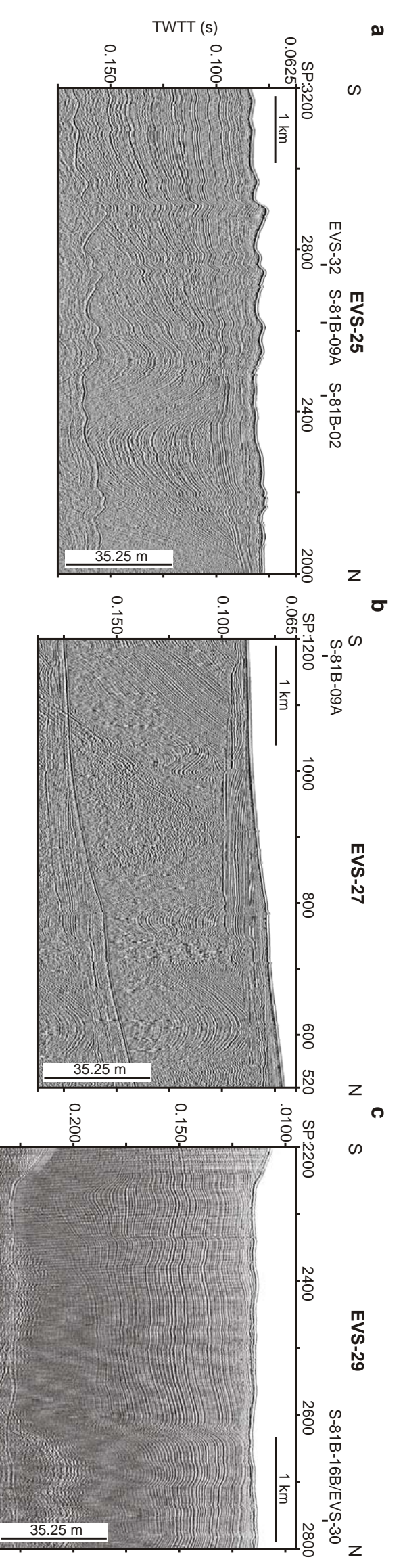

www.nat-hazards-earth-syst-sci.net/12/3151/2012/ 
The Guardamar zone is a large deformation area with a WSW-ENE direction and a length of up to $50 \mathrm{~km}$. It is located between the Bajo Segura and La Mata synclines (Giménez et al., 2009), to the north and south, respectively (Figs. 3 and 8). The La Mata syncline propagates around $20 \mathrm{~km}$ from the onshore towards the sea, progressively changing its direction from NW-SE to WSW-ENE. The faults located on both sides of the Guardamar zone produced the uplift of the area and a regional antiform. As a result, the Neogene basement is elevated and, in some areas, exposed on the seafloor (Figs. 6 and $9 \mathrm{~b}$ ). The structures located to the north of the antiform may be correlated with the BSFZ and the Guardamar anticline (Figs. 3, 6 and 9b). Both structures extend along the study area. The commercial MCS profiles show that the BSFZ is composed of thrust faults that dip towards the south (i.e. are folding units III and II). Moreover, the SCS sparker profiles show that the BSFZ separates in some minor sub-vertical faults that offset horizon H1. The structures located to the south of the Guardamar high are not correlated with specific onshore structures and taper off towards the center of the shelf. In the commercial MCS profiles, the faults usually dip towards the center of the antiform and affect units III and II. The analysis of the SCS sparker profiles shows that most of the faults are sealed by horizon H1. However, some faults could displace reflectors above H1 (Figs. 6 and 9b). The folds clearly deform units III and II, which are very close to the seafloor surface. The horizons developed above these folds are apparently not folded in the SCS sparker profiles.

The Cabo Cervera zone (Fig. 8) is located between the La Mata syncline to the north (Fig. 9a) and some small synclines to the south (Fig. 6). The structures located along the Cabo Cervera zone have an E-W to WSW-ENE direction and continue up to $15 \mathrm{~km}$ offshore. In the commercial MCS profiles, the faults are sub-vertical and offset unit III and probably unit II, which is folded (Alfaro et al., 2002b). The SCS sparker profiles show some faults reaching and deforming the seafloor (Fig. 5). The TF extends offshore with some uncertainty. Nevertheless, the CCF2 faults have been recently active (Fig. 5) and could be related to TF. The Cabo Cervera anticline also extends offshore. This anticline probably folds horizon $\mathrm{H} 1$, but decreases in amplitude before tapering off around $10 \mathrm{~km}$ from the coastline.

The Salinas de Torrevieja zone is located south of the Cabo Cervera zone (Fig. 8). A number of synclines and anticlines continue offshore around 15 to $20 \mathrm{~km}$ from the coastline (Fig. 6). These folds have two different directions. The northeastern ones have an E-W trend, a low amplitude and do not deform the reflectors above horizon H2. In contrast, the folds identified in the south have a WNW-ESE trend, a larger amplitude and slightly fold the reflectors above H2 and near H1 (Fig. 6). The Torrevieja syncline described onshore (Montenat, 1977; Somoza, 1993; Alfaro et al., 2002a; Giménez et al., 2009) extends offshore in a WNW-ESE direction for more than $20 \mathrm{~km}$.
The southernmost zone is the San Miguel de Salinas zone (Fig. 8). The structures identified in this zone change from WNW-ESE in the north to E-W in the south, and continue for $15 \mathrm{~km}$ offshore. Most of the faults are sub-vertical and offset horizon $\mathrm{H} 2$ and, in some places, also horizon H1. Both horizons are folded. As a result of the correlation with the structures described onshore (Montenat, 1977; Alfaro et al., 2002a; Giménez et al., 2009), the SMSF, the Punta Prima anticline and the Cala del Bosque syncline extend offshore.

\section{Discussion}

\subsection{Style of deformation}

As stated above, the present regional stress field in the Bajo Segura basin is compressive and trends NW-SE to N-S. Accordingly, most of the described structures, faults and folds, have a compressive component in their kinematics and trend WSW-ENE to W-E (Figs. 3, 6 and 8). Taboada et al. (1993) considered three hypotheses in an attempt to explain the deformation undergone in the Bajo Segura basin and to account for the geometrical relationships between the main faults (BSFZ, TF and SMSF) and anticlines (the Guardamar, Cabo Cervera and Punta Prima). The first hypothesis considers that each anticline was created by an independent blind thrust. By contrast, the second and third hypotheses propose that all the faults branch into a common detachment layer at depth. Moreover, the Guardamar and Cabo Cervera anticlines would be associated with a thrust system with flatramp geometry. The difference between the two hypotheses is that one considers that both anticlines are related to blind thrusts, whereas the other assumes that only the Guardamar anticline is produced by a thrust. Analysis of the commercial MCS profiles S-81B-07A (Fig. 3) and S-81B-09 (Alfaro et al., 2002b), which have directions similar to those of the cross section provided by Taboada et al. (1993), shows the following: (a) there is no shallow (1 km depth) detachment layer that could be identified as the flat zone of flat-ramp thrust geometry; by contrast the BSFZ, TF and SMSF seem deeply rooted in the crust since they show high dip angles; (b) there is a predominance of thrust kinematics only in the BSFZ; (c) the TF and SMSF are more vertical and produce less uplift than the BSFZ, indicating that their thrust kinematics is much lower and that the strike-slip component is prevalent. In line with these observations, the second and third hypotheses of Taboada et al. (1993) could be discarded even though these hypotheses offer a better reproduction of the deformation at the base of the Pliocene. Furthermore, the first hypothesis should consider a main strike-slip component in the TF and SMSF. From the Bajo Segura fault to the north, there is a predominance of compressive structures (thrust faults and anticlines) that uplift the La Marina and Santa Pola highs (Fig. 3). There are few structures in this uplifted area, 
the most significant being the anticline associated with fault LMF2, which has been correlated with La Marina anticline.

\subsection{Timing of deformation}

The activity of faults and folds identified in the Bajo Segura basin began in the Upper Miocene and continues during the Quaternary (Alfaro, 1995; Montenat et al., 1990). The commercial MCS profiles show that faults and folds deform units III and II, Upper Miocene and Pliocene in age, respectively, but it is not certain whether they affect unit I, which corresponds to the Quaternary (Fig. 3). However, the analysis of the SCS sparker profiles shows that most of the structures that were active during the Pliocene have been active during the Quaternary (Figs. 5, 6 and 9). As stated above, the different deformation zones show faults and folds that deform horizon H2. Some of these structures also affect horizon $\mathrm{H} 1$, and very few reach the seafloor surface (Figs. 5 and 9). In line with these observations and with the ages given to the different horizons, most of the structures were active until $135 \mathrm{ka}$ and in some cases this activity postdates $20 \mathrm{ka}$. Considering the available slip rates of the main faults in the area, which vary between 0.12 and $0.40 \mathrm{~mm} \mathrm{yr}^{-1}$ (Somoza, 1993; García-Mayordomo and Martíniez-Díaz, 2006; Giménez et al., 2009; Alfaro et al., 2012; García-Mayordomo et al., 2012), some authors have calculated the recurrence intervals of the large earthquakes, which range between 1700 and $30000 \mathrm{yr}$ (Alfaro et al., 2012; García-Mayordomo et al., 2012). Thus, reflectors above horizon H1 were probably deformed by very few earthquakes. Moreover, the deformation produced by a single event could be distributed over a wide area given that the main structures of the zone are anticlines associated with blind faults. These two reasons would suggest that the accumulated offset in not necessarily visible in the resolution of the SCS sparker profiles. In conclusion, following this reasoning, the structures affecting the reflectors just below or above horizon $\mathrm{H} 2$ can be considered as active during the Quaternary and capable of causing large earthquakes.

\subsection{Possible sources of the 1829 Torrevieja earthquake}

On 21 March 1829, the province of Alicante was struck by a large earthquake known as the Torrevieja earthquake ( $I_{\text {EMS } 98}$ IX-X). This is one of the largest historical earthquakes in Spain and the strongest shock of a seismic sequence that affected the province of Alicante during 1828 and 1829 (López Marinas, 1976; Mezcua, 1982; Rodríguez de la Torre, 1984; Muñoz et al., 1984; Albini and Rodríguez de la Torre, 2001; Martínez Solares and Mezcua, 2002). According to historical records, the Torrevieja earthquake was felt over a large area, caused a great deal of damage to the epicentral area (e.g. the villages of Almoradí, Benejúzar and Torrevieja were completely destroyed) and about 389 casualties (Larramendi, 1829; Galbis, 1932). Considerable liquefaction occurred in the Bajo Segura Plain onshore (Larramendi, 1829; Rodríguez de la Torre, 1984; Alfaro, 1995; Alfaro et al., 1999; Soria et al., 1999). Earthquake magnitudes between 6.0 and 6.9 and focal depths between 3 and $7 \mathrm{~km}$ have been estimated for this event by different authors (Muñoz and Udías, 1991; Delgado et al., 1993; Giner, 1996; Martínez Solares and Mezcua, 2002; García-Mayordomo and Martínez-Díaz, 2006). The question still open is about which fault generated the 1829 Torrevieja earthquake. The most recent compilations and reevaluations of intensity data points include 67 localities where the 1829 Torrevieja earthquake caused damage to buildings and/or was felt by the population (Albini and Rodríguez de la Torre, 2001; Martínez Solares and Mezcua, 2002). The highest intensities ( $I_{\mathrm{EMS} 98} \mathrm{IX}-\mathrm{X}$ and IX) were felt between Benejúzar and Guardamar, from west to east, and between Almoradí and Torrevieja, from north to south. This geographical distribution of the highest intensities points to the BSFZ and TF as being the most likely sources of the earthquake (Fig. 10). Moreover, given the lack of information about intensity offshore and the location of some of the highest values close to the coastline, the earthquake could have resulted from the rupture of an offshore segment of one of these two faults. The analysis of the SCS sparker profiles obtained in this area could provide some new information about the identification of the earthquake source.

The first candidate to be the 1829 earthquake source is the BSFZ (Figs. 2, 8 and 10). This is a WSW-ENE trending blind thrust with the hanging wall directed towards the NW. This is a blind fault that deforms the surface with several anticlines affecting the Plio-Quaternary units (Taboada et al., 1993; Alfaro, 1995). Using different geological markers and high-precision leveling data, an uplift rate of around $0.2 \mathrm{~mm} \mathrm{yr}^{-1}$ has been estimated around the BSFZ (Somoza, 1993; Sanz de Galdeano et al., 1998; García-Mayordomo and Martínez-Díaz, 2006; Giménez et al., 2009). Alfaro et al. (2002a) interpreted this structure as the most likely source fault and located the focus between the Segura River and Torrevieja, considering the evidence of Quaternary activity and the southward dip of the BSFZ. This would explain the considerable damage and high intensities around Torrevieja as well as the liquefaction and local site effects observed in the basin villages. Analysis of the SCS sparker profiles shows that some minor faults, related to the BSFZ, offset horizon $\mathrm{H} 2$ and maybe H1 (Figs. 6 and 9b). Thus, the offshore part of the Bajo Segura fault has been active during the Upper Quaternary, with possible deformation events in the last $20 \mathrm{ka}$. The total length of the Bajo Segura fault onshore is $27 \mathrm{~km}, 10 \mathrm{~km}$ corresponding to the Hurchillo, $9 \mathrm{~km}$ to the Benejúzar and $8 \mathrm{~km}$ to the Guardamar segments (Alfaro et al., 2012). On the basis of the correlation between the different seismic profiles, the BSFZ can be traced for at least $27 \mathrm{~km}$ offshore. Considering these different dimensions as the surface rupture length of an earthquake and using empirical relationships for reverse faults (Wells and Coppersmith, 1994), a moment magnitude (Mw) ranging between 6.1 and 


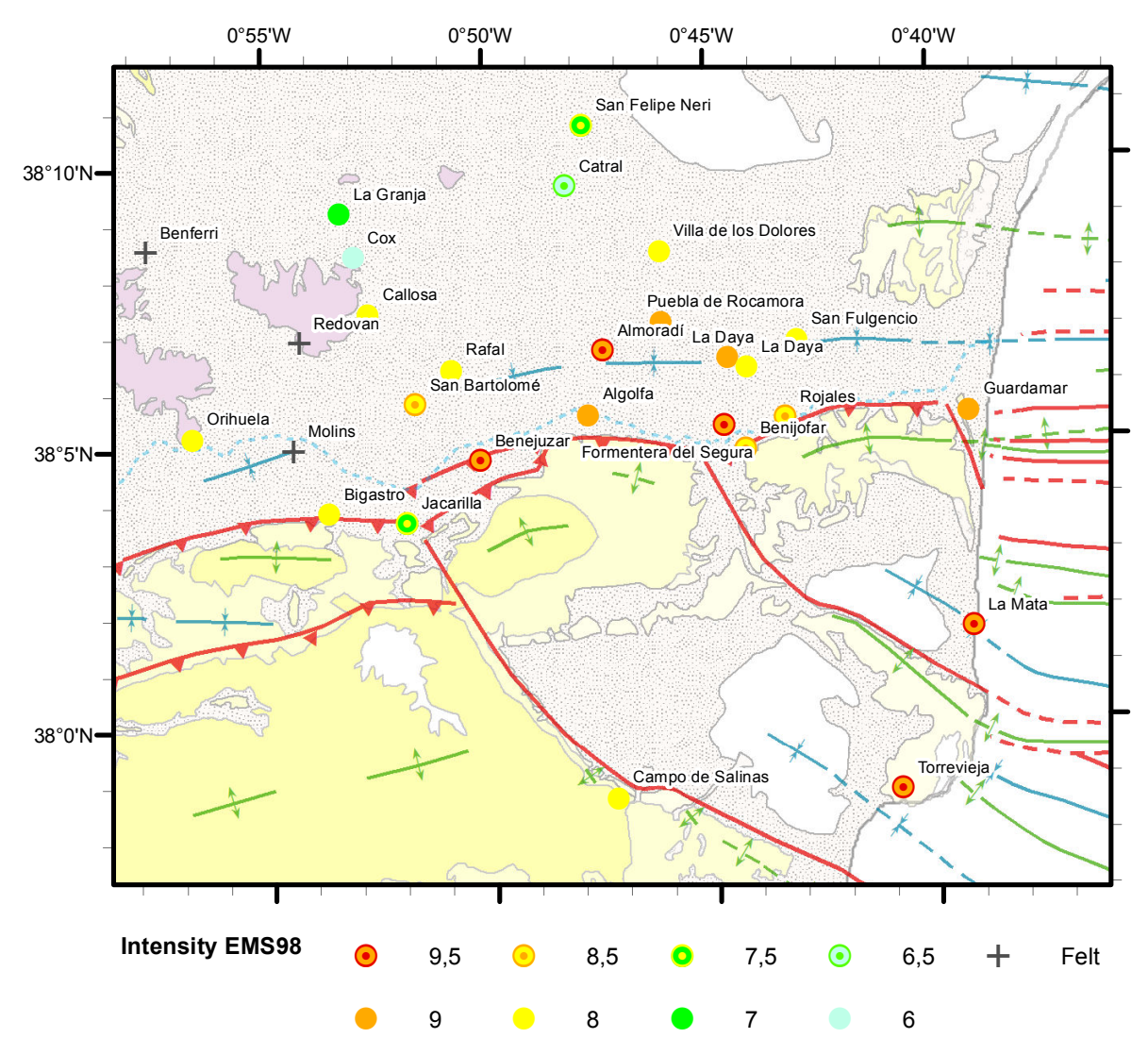

Fig. 10. Geological map of the Bajo Segura basin (Alfaro et al., 2002a, b) showing the distribution of the intensity data points of the 21 March 1829 Torrevieja earthquake (Martínez Solares and Mezcua, 2002). Note that the area where the maximum intensities are located suggests that the BSFZ or the TF are the most likely sources of this earthquake.

6.7 is obtained. Thus, these ruptures would yield magnitudes in the range of magnitudes estimated by other authors for this earthquake. Nevertheless, the highest magnitude (Mw 6.9) is only obtained when the length of the Guardamar and the offshore segments are considered to be the earthquake rupture $(35 \mathrm{~km})$. This maximum magnitude is exceeded when assuming that the entire fault (onshore and offshore segments) ruptures together $(54 \mathrm{~km}, \mathrm{Mw} 7.1)$.

The second candidate, the TF (Figs. 2 and 8), is a NW-SE trending right-lateral strike-slip fault with a reverse component. Although the fault is difficult to follow along the zone, its present activity is evidenced by the presence of the Cabo Cervera anticline where the Plio-Pleistocene sedimentary units are folded. Besides, the fault could have produced some lateral displacement of the BSFZ, which is active (Fig. 2). The estimated slip rate of the TF is $0.075 \mathrm{~mm} \mathrm{yr}^{-1}$ because of the displacement of the Upper Pliocene structural surface (García-Mayordomo and Martínez-Díaz, 2006). On the basis of a statistical study of the intensities assigned to some localities during the 1829 Torrevieja earthquake (López Marinas, 1976; Muñoz et al., 1984; López Casado et al., 1992), and assuming that the source model is linear, Delgado et al. (1993) obtained a fault source that better reproduced these intensi- ties. This fault trended NW-SE, extended offshore and may be correlated with the TF. Thus, as in the case of the BSFZ, an earthquake along the TF could also have accounted for the destruction in the area. Furthermore, rupture propagation from offshore towards the northwest could explain the considerable damage in the Bajo Segura basin. Nevertheless, a shallow earthquake with an estimated magnitude higher than 6.0 would produce surface rupture, which has not been described in the area. The existing reports concern a large fracture in a coastal and rocky outcrop between Torrevieja and La Mata (Larramendi, 1829), which could also be a landslide scar. As in the onshore, the offshore continuation of the TF is uncertain. However, the Cabo Cervera anticline can be identified and extends for around $10 \mathrm{~km}$. The CCF2 faults are associated with both structures and reach and offset the seafloor surface (Fig. 5), indicating recent activity. Assuming that the Cabo Cervera anticline is directly related to the activity of the fault, the onshore and offshore lengths of the TF are similar, about $12 \mathrm{~km}$ each (García-Mayordomo and Martínez-Díaz, 2006). Considering the length of these individual segments to be the maximum surface rupture and using empirical relationships for reverse and strike-slip faults (Wells and Coppersmith, 1994), a Mw 6.3 is obtained. Magnitude attains 6.7 
when both segments are regarded as rupturing together. With this fault source, the maximum estimated magnitude for the earthquake (Mw 6.9) is not reached.

As stated above, the BSFZ and the TF show Upper Quaternary activity. In some cases, this activity postdates horizon H1 or even implies the deformation of the seafloor surface. Thus, it may well be that the fault rupture or part of the rupture that caused the 1829 Torrevieja earthquake was located offshore. Nevertheless, no tsunami was reported to be associated with this event. The rupture of individual segments of these two faults or some combinations of them could produce an earthquake with magnitudes in the range estimated for this event.

Much work has been done in the area substantially improving the imaging and characterization of the active/recent tectonic structures. However, there is no definite evidence yet about which fault caused the 1829 earthquake. Therefore, further studies (e.g. swath-microbathymetry, sub-bottom profiling or more SCS sparker profiles offshore) are warranted to improve our understanding of the recent Quaternary activity of both faults and of the seismic hazard in the northern termination of the EBSZ.

\section{Conclusions}

The analysis of the SCS sparker profiles obtained in the offshore Bajo Segura basin allowed us to identify six seismostratigraphic units (I1 to I6) limited by five horizons (H1 to H5). These horizons can correspond to regional erosional surfaces produced during the Quaternary global sea level lowstands and then can be correlated with marine isotopic stages (MIS). We propose that (a) H1 may be correlated to MIS2 (20 ka), (b) H2 to MIS6 (135 ka), (c) H3 to MIS8.2 (247.6 ka), (d) H4 to MIS10 (341 ka), and (e) H5 to MIS 12 (434 ka).

A number of faults and folds affecting the Quaternary sediments were mapped for the first time in the Bajo Segura offshore basin. Most of these structures trend WSW-ENE to $\mathrm{W}-\mathrm{E}$ and show a compressive component in their kinematics, which is in agreement with the present regional stress field. The main faults described onshore were correlated with those identified offshore. Six deformation zones bounded by regional synclines were proposed in line with the main onshore structures: (a) Santa Pola zone; (b) La Marina zone; (c) Guardamar zone; (d) Cabo Cervera zone; (e) Torrevieja zone; and (f) San Miguel de Salinas zone.

Integrated analysis of the commercial MCS and SCS sparker profiles shows that (a) the main faults (e.g. BSFZ, $\mathrm{TF}$ and SMSF) have high dip angles and are deeply rooted in the crust; (b) the thrust kinematics predominates in the BSFZ and to the north, and is underlined by the formation of anticlines; and (c) the strike-slip kinematics prevails in the TF and SMSF, despite the fact that these faults formed the Cabo Cervera and Punta Prima anticlines, respectively.
The relations between the seismo-stratigraphic discontinuities and the faults and folds that deform them provide evidence of recent Quaternary activity in the Bajo Segura basin. Most of the faults are sealed or offset horizon H2 (135 ka), and in some cases their activity postdates the formation of horizon H1 (20 ka). The structures that deform horizon H2 may therefore be considered active and capable of producing destructive earthquakes.

Because of the distribution of the intensity data points and of the recent tectonic activity, both the BSFZ and TF could represent the most likely sources for the 1829 Torrevieja earthquake. Analysis of the length of both faults and fault segments onshore and offshore shows that almost all of the fault segments forming both BSFZ and TF are capable of producing a magnitude in the range of the magnitudes estimated for the 1829 earthquake (Mw between 6.0 and 6.9). Nevertheless, the maximum magnitude is attained or exceeded in the BSFZ when the rupture involves the Guardamar and offshore segments (Mw 6.9) or the entire fault $(\mathrm{Mw}$ 7.1). Further studies are warranted to provide more insight into the recent Quaternary activity of both faults.

Acknowledgements. The authors are indebted to Domenico Ridente, Juan José Martínez Díaz and an anonymous reviewer whose helpful comments and suggestions have considerably improved the manuscript. Thanks are due to Daniela Pantosti for editing this manuscript. The authors acknowledge the support of the Spanish Ministry of Science and Innovation through National Projects IMPULS (REN2003-05996MAR), EVENT (CGL 2006-12861C02-02) and SHAKE (CGL 2011-30005-C02-02); Acciones Complementarias EVENT-SHELF (CTM 2008-03346-E/MAR) and SPARKER (CTM 2008-03208-E/MAR); and ESF TopoEurope TOPOMED project (CGL 2008-03474-E/BTE). We are grateful to the captain, crew and science party onboard the RV Garcia del Cid. Hector Perea was a researcher at IDL-UL Associated Laboratory under contract no. 3/2010/LAB_IDL co-financed by the Portuguese FCT and FEDER and at UTM-CSIC under the Juan de la Cierva contract no. JCI-2010-07502 funded by the Spanish Ministry of Science and Innovation.

Edited by: D. Pantosti

Reviewed by: J. Martinez-Diaz, D. Ridente, and one anonymous referee

\section{References}

Albini, P. and Rodríguez de la Torre, F.: The 1828-1829 earthquake sequence in the provinces of Alicante and Murcia (S-E Spain): Historical sources and macroseismic intensity assessment, in: The use of historical data in natural hazard assessments, edited by: Glade, T., Albini, P., and Frances, F., 35-53, 2001.

Alfaro, P.: Neotectónica en la Cuenca del Bajo Segura (Cordillera Bética Oriental), PhD Thesis, Universidad de Alicante, Alicante, 217 pp., 1995.

Alfaro, P., Estévez, A., Moretti, M., and Soria, J. M.: Structures sédimentaires de déformation interprétées comme séismites dans 
le Quaternaire du bassin du Bas Segura (Cordillère bétique orientale), C. R. Acad. Sci. Paris, 328, 17-22, 1999.

Alfaro, P., Andreu, J. M., Delgado, J., Estevez, A., Soria, J., and Teixidó, T.: Quaternary deformation of the Bajo Segura blind fault (eastern Betic Cordillera, Spain) revealed by highresolution reflection profiling, Geological Magazine, 139, 331341, 2002a.

Alfaro, P., Delgado, J., Estévez, A., Soria, J. M., and Yébenes, A.: Onshore and offshore compressional tectonics in the eastern Betic Cordillera (SE Spain), Marine Geology, 186, 337-349, 2002b.

Alfaro, P., Bartolomé, R., Borque, M.J., Estévez, A., GarcíaMayordomo, J., García-Tortosa, F. J., Gil, A. J., Gràcia, E., Lo Iacono, C., and Perea, H.: The Bajo Segura Fault Zone: Active blind thrusting in the Eastern Betic Cordillera (SE Spain), Journal of Iberian Geology, 38, 271-284, 2012.

Archivo Técnico de Hidrocarburos: http://hidrocarburos.mityc.es/ ath/, last access: 27 June 2012.

Argus, D. F., Gordon, R. G., DeMets, C., and Stein, S.: Closure of the Africa-Eurasia-North America Plate Motion Circuit and Tectonics of the Gloria Fault, J. Geophys. Res., 94, 5585-5602, 1989.

Bisbal, L.: Estudio de la distribución de intensidades sísmicas en el ámbito valenciano. Sus incidencias en las obras públicas. Tomo V: Estudio monográfico de la serie sísmica del 23-3-1748 al 8-41748 con epicentro en Estubeny (tradicionalmente llamado terremoto de Montesa), Universitat Politècnica de València, 1984.

Bousquet, J. C.: Quaternary strike-slip faults in southeastern Spain, Tectonophysics, 52, 277-286, 1979.

Buforn, E., Sanz de Galdeano, C., and Udias, A.: Seismotectonics of the Ibero-Maghrebian region, Tectonophysics, 248, 247-261, 1995.

De Larouzière, F. D., Bolze, J., Bordet, P., Hernandez, J., Montenat, Ch., and Ott d'Estevou, Ph.: The Betic segment of the lithospheric Trans-Alborán shear zone during the Late Miocene, Tectonophysics, 152, 41-52, 1988.

Delgado, J., Giner, J. J., López Casado, C., and Auernheimer, C.: Análisis de la respuesta del suelo en intensidades. Aplicación al terremoto de Torrevieja, in: Problemàtica geoambiental y desarrollo. V reunión nacional de geología ambiental y ordenación del territorio II, edited by: Ortiz, R., 627-636, 1993.

DeMets, C., Gordon, R. G., Argus, D. F., and Stein, S.: Current plate motions, Geophys. J. Int., 101, 425-478, 1990.

Focault, A.: Étude géologique des environs des sources du Guadalquivir (provinces de Jaen et de Grenade, Espagne méridionale), PhD Thesis, University of Paris VI, 633 pp., 1974.

Galbis, J.: Catálogo sísmico de la zona comprendida entre los meridianos $5 \mathrm{E}$ y $20 \mathrm{~W}$ de Greenwich y los paralelos $45 \mathrm{~N}$ y $25 \mathrm{~N}$, Instituto Geográfico Catastral y de Estadística, Madrid, 807 pp., 1932.

García-Mayordomo, J. and Martínez-Díaz, J.J.: Caracterización sísmica del anticlinorio del Bajo Segura (Alicante): Fallas del Bajo Segura, Torrevieja y San Miguel de Salinas, Geogaceta, 40, 19-22, 2006.

García-Mayordomo, J., Insua-Arévalo, J. M., Martínez-Díaz, J. J., Jiménez-Díaz, A., Martín-Banda, R., Martín-Alfageme, S., Alvárez-Gomez, J. A., Rodríguez-Peces, M., Pérez-López, R., Rodríguez-Pascua, M. A., Masana, E., Perea, H., MartínGonzález, F., Giner-Robles, J., Nemser, E. S., Cabral, J., and the
QAFI Compilers Working Group: The Quaternary Active Faults DataBase of Iberia (QAFI v.2.0), Journal of Iberian Geology, 38, 285-302, 2012.

Giménez, J., Borque, M., Gil, A., Alfaro, P., Estévez, A., and Suriñach, E.: Comparison of long-term and short-term uplift rates along an active blind reverse fault zone (Bajo Segura, Se Spain), Studia Geophysica et Geodaetica, 53, 81-98, 2009.

Giner, J. J.: Sismicidad y peligrosidad sísmica en la comunidad autónoma valenciana. Análisis de incertidumbres, $\mathrm{PhD}$ Thesis, Universidad de Granada, 295 pp., 1996.

Giner, J. J., Molina, S., and Jáuregui, P. J.: Sismicidad en la Comunidad Valenciana (C.V.), Física de la Tierra, 15, 163-187, 2003.

Grimison, N. and Cheng, W.: The Azores-Gibraltar plate boundary: focal mechanisms, depths of earthquakes and their tectonic implications, J. Geophys. Res., 91, 2029-2047, 1986.

IGN: Catálogo de terremotos en el área de la Península Iberica e Islas Canarias (http://www.01.ign.es/ign/layoutIn/ sismoFormularioCatalogo.do), last access October 2011.

Koulali, A., Ouazar, D., Tahayt, A., King, R. W., Vernant, P., Reilinger, R. E., McClusky, S., Mourabit, T., Davila, J. M., and Amraoui, N.: New GPS constraints on active deformation along the Africa-Iberia plate boundary, Earth Planet. Sci. Lett., 308, 211-217, 2011.

Lanaja, J. M., Querol, R., and Navarro, A.: Contribución de la exploración petrolífera al conocimiento de la Geología de España. IGME, Madrid. 465 pp., 1987.

Larramendi, J. A.: Memoria y relación circunstanciada de los estragos que la terrible catástrofe de los terremotos de 21 de Marzo y siguientes, principalmente el Sábado Santo 18 de Abril hasta el presente día, han causado en Torrevieja y demás pueblos de la Gobernación de Orihuela y sus inmediaciones, en la ciudad de Murcia y algunos pueblos de este nombre, Imprenta Real, Madrid, 24 pp., 1829.

Lo Iacono, C., Sulli, A., Agate, M., Lo Presti, V., Pepe, F., and Catalano, R.: Submarine canyon morphologies in the Gulf of Palermo (Southern Tyrrhenian Sea) and possible implications for geo-hazard, Marine Geophys. Res., 32, 127-138, 2011.

López Casado, C., Estévez, A., Pina, J., and Sanz de Galdeano, C.: Alineaciones sismotectónicas en el sudeste de España, Ensayo de delimitación de fuentes sísmicas, Serie de Estudios Geológicos, 6, 5-39, 1987.

López Casado, C., Peinado, M. A., Delgado, J., Peláez, J. A., and Fuentes, C.: La serie sísmica de Torrevieja de 1828 y 1829, I Congreso Iberoamericano sobre técnicas aplicadas a la gestión de emergencias para la reducción de desastres naturales, Valencia, 1992.

López Marinas, J. M.: Sismo del 21 de Marzo de 1829, Madrid, 1976.

Martínez Solares, J. M. and Mezcua, J.: Catálogo sísmico de la Península Ibérica (880 a.C. - 1900), Instituto Geográfico Nacional - Monografia no. 18, 444 pp., 2002.

Mezcua, J.: Catálogo general de isosistas de la Península Ibérica, IGN, Madrid, 320 pp., 1982.

Montenat, C.: Les bassins néogènes et quaternaires du levant d'Alicante à Murcie (Cordillères Bètiques Orientales, Espagne), Stratigraphie, paléontologie et évolution dynamique, $\mathrm{PhD}$ Thesis, Laboratoire Géologique, University of Lyon, 345 pp., 1977.

Montenat, C., Ott D'Estevou, P., and Coppier, G.: Les bassins néogènes entre Alicante et Cartagena, in: Les bassins néogènes 
du domaine Bétique orientale (Espagne), Doc. Trav. IGAL, 313368, 1990.

Morel, J. L. and Meghraoui, M.: Goringe-Alboran-Tell tectonic zone: A transpression system along the Africa-Eurasia plate boundary, Geology, 24, 755-758, 1996.

Muñoz, D. and Udías, A.: Three large historical earthquakes in southern Spain, in: Seismicity, seismotectonics and seismic risk of the Ibero Maghrebian region, IGN, 175-182, 1991.

Muñoz, D., Udias, A., and Moreno, E.: Reevaluación de los datos del terremoto del 1829 (Torrevieja), in: Sismicidad histórica de la Península Ibérica, Asociación Española de Ingeniería Sísmica, Madrid, 38-41, 1984.

Perea, H., Gràcia, E., Bartolomé, R., Lo Iacono, C., and Masana, E.: Structure and potential seismogenic sources of the offshore Bajo Segura Fault Zone, SE iberian Peninsula (Mediterranean sea). Looking for the source of the 1829 Torrevieja earthquake, in: Contribución de la geología al análisis de la peligrosidad sísmica, edited by: Insua, J. M. and Martín-González, F., 113-116, 2010.

Rabineau, M., Berné, S., Olivet, J.-L., Aslanian, D., Guillocheau, F., and Joseph, P.: Paleo sea levels reconsidered from direct observation of paleoshoreline position during Glacial Maxima (for the last 500,000 yr), Earth Planet. Sci. Lett., 252, 119-137, 2006.

Ridente, D., Fracassi, U., Di Bucci, D., Trincardi, F., and Valensise, G.: Middle Pleistocene to Holocene activity of the Gondola Fault Zone (Southern Adriatic Foreland): Deformation of a regional shear zone and seismotectonic implications, Tectonophysics, 453, 110-121, 2008.

Rodríguez de la Torre, F.: Los terremotos alicantinos de 1829, Publicaciones del instituto de estudios alicantinos, Alicante, 1984.

Sanz de Galdeano, C., El Hamdouni, R., Chacón, J., Gómez, A., Salvador, F., Schulte, L., and García, A.: Neotectónica de la fosa del Padúl y del Valle de Lecrín, in: Itinerario geomorfológico por Andalucía Oriental, Publicaciones de la Universidad de Barcelona, 65-81, 1998.
Sanz de Galdeano, C., López, C., Delgado, J., and Peinado, M. A.: Shallow seismicity and active faults in the Betic Cordillera. A preliminary approach to seismic sources associated with specific faults, Tectonophysics, 248, 293-302, 1995.

Serpelloni, E., Vannucci, G., Pondrelli, S., Argnani, A., Casula, G., Anzidei, M., Baldi, P., and Gasperini, P.: Kinematics of the Western Africa-Eurasia plate boundary from focal mechanisms and GPS data, Geophys. J. Int., 169, 1180-1200, 2007.

Silva, P. G., Goy, J. L., Somoza, L., Zazo, C., and Bardají, T.: Landscape response to strike-slip faulting linked to collisional settings: Quaternary tectonics and basin formation in the Eastern Betics, southeastern Spain, Tectonophysics, 224, 289-303, 1993.

Somoza, L.: Estudio del Cuaternario litoral entre el Cabo de Palos y Guardamar (Murcia-Alicante). Las variaciones del nivel del mar en relación con el contexto geodinámico, Instituto Español de Oceanografía, 237 pp., 1993.

Soria, J. M., Alfaro, P., Estévez, A., Delgado, J., and Durán, J. J.: The Holocene sedimentation rate in the Lower Segura Basin (eastern Betic Cordillera): eustatic implications, Bull. Soc. Géol. France, 170, 349-354, 1999.

Taboada, A., Bousquet, J. C., and Philip, H.: Coseismic elastic models of folds above blind thrusts in the Betic Cordilleras (Spain) and evaluation of seismic hazard, Tectonophysics, 220, 223-241, 1993.

Vernant, P., Fadil, A., Mourabit, T., Ouazar, D., Koulali, A., Davila, J. M., Garate, J., McClusky, S., and Reilinger, R.: Geodetic constraints on active tectonics of the Western Mediterranean: Implications for the kinematics and dynamics of the Nubia-Eurasia plate boundary zone, J. Geodynamics, 49, 123-129, 2010.

Wells, D. L. and Coppersmith, K. J.: New empirical relationships among magnitude, rupture length, rupture width, rupture area, and surface displacement, Bull. Seismol. Soc. America, 84, 974$1002,1994$. 